\title{
Efeito da suplementação de colostro enriquecido sobre as características morfológicas da mucosa intestinal de bezerros neonatos*
}

Effects of enriched colostrum supply in intestinal mucosa morphology of newborn calves*

\author{
Liris Kindlein', Patricia Pauletti ${ }^{2}$, Adriana Regina Bagaldo ${ }^{3}$, Ana Paula Oeda Rodrigues², \\ Raul Machado-Neto ${ }^{2}$
}

\begin{abstract}
Colostrum intake in neonatal calves is essential to obtain passive immunity and to influence metabolism, endocrine systems and the nutritional state. This study compares morphologic features of small intestine of calves fed a colostrum second meal at 12 hours of life with concentrations of immunoglobulin $\mathrm{G}(\mathrm{IgG})$ higher than $100 \mathrm{mg} \mathrm{mL}^{-1}$ (fresh colostrum or artificially prepared with addition of lyophilized colostrum) or smaller than $30 \mathrm{mg} \mathrm{mL}^{-1}$. Twenty-four Holstein calves were randomly grouped according to concentration of IgG intake at 12 hours of life: low (less than $30 \mathrm{mg} \mathrm{mL}^{-1}$ ); high (more than $100 \mathrm{mg} \mathrm{mL}^{-1}$ ); plus lyophilized colostrum (more than $120 \mathrm{mg} \mathrm{mL}^{-1}$ ). Intestinal tissue samples were collected at $0,10,24$ and 72 hours after birth to evaluate morphology in segments: duodenum; proximal, middle and distal jejunum and ileum by examined with a scanning electron microscope. Villi of all segments showed more organized and uniform morphology characteristics with age. Only the animals fed colostrum with more than $100 \mathrm{mg} \mathrm{mL}^{-1}$ of $\operatorname{IgG}$ at 24 hours after birth still showed the distal jejunum villi disoriented and more united in comparison to the other ages and groups. Intake of lyophilized colostrum affected ileum morphology along experiment period. Higher concentration of immunologic and bioactive elements supplied for longer period of time could be responsible for promoting effects on the enterocytes. Use of colostrum with high IgG concentrations, with or without addition of lyophilized colostrum, influenced the precocity of the intestinal mucosa development in newborn calves, suggesting earlier maturation of the mucosa.
\end{abstract}

Key words: enterocyte, immunoglobulin, intestinal mucosa, lyophilized colostrums, scanning electron microscopy.

\section{RESUMO}

A ingestão de colostro em bezerros neonatos é essencial na aquisição de imunidade passiva e também influencia sobre o metabolismo, o sistema endócrino e o estado nutricional. O presente estudo compara características morfológicas do intestino delgado de bezerros suplementados com uma segunda refeição de colostro, administrada às 12 horas de vida, com concentração de imunoglobulina $\mathrm{G}(\mathrm{IgG})$ superior a $100 \mathrm{mg} \mathrm{mL}^{-1}$ (fresco ou adicionado de colostro liofilizado) ou inferior a 30 $\mathrm{mg} \mathrm{mL} \mathrm{m}^{-1}$. Vinte e quatro bezerros da raça Holandesa foram agrupados, aleatoriamente, de acordo com a concentração de $\operatorname{IgG}$ ingerida às 12 horas de vida: baixa (inferior a $30 \mathrm{mg} \mathrm{mL}^{-1}$ ); elevada (superior a $100 \mathrm{mg} \mathrm{mL}^{-1}$ ); adicionada de colostro liofilizado (superior a $120 \mathrm{mg} \mathrm{mL}^{-1}$ ). As amostras do tecido intestinal foram coletadas às $0,10,24$ e 72 horas após o nascimento para avaliação da morfologia do duodeno; jejuno proximal, médio e distal e íleo através de microscopia eletrônica de varredura. Os vilos de todos os segmentos mostraram características morfológicas mais organizadas e uniformes com o decorrer da idade. Às 24 horas de vida, somente os vilos do jejuno distal dos animais que receberam colostro com concentração de IgG superior a $100 \mathrm{mg} \mathrm{mL}^{-1}$, apresentaram-se mais desordenados e unidos comparados às outras idades e grupos. A ingestão de colostro liofilizado afetou a morfologia do íleo em todas as idades. O fornecimento de colostro de alta concentração de imunoglobulinas e de elementos bioativos, por um período prolongado, pode promover efeitos nos enterócitos. O uso do colostro com concentrações elevadas de IgG, com ou sem adição do colostro liofilizado, influenciou o desenvolvimento da mucosa intestinal dos bezerros neonatos, sugerindo maturação precoce da mucosa.

Descritores: colostro liofilizado, enterócitos, imunoglobulina, microscopia eletrônica de varredura, mucosa intestinal. 


\section{INTRODUCTION}

Colostrum intake in neonatal calves is essential to obtain passive immunity and to influence metabolism, endocrine systems and the nutritional state [4]. Furthermore, ingestion of colostrum stimulates the development of the gastrointestinal tract in neonatal calves [5]. Therefore, intestinal absorptive capacity in neonatal calves was lower in calves fed milk replacer compared to those fed colostrum [7]. The hypothesis that fedding calves a colostrum second meal at 12 hours of life with $\mathrm{IgG}$ concentration higher than $100 \mathrm{mg}$ $\mathrm{mL}^{-1}$ would influence the morphology features of the small intestine was tested.

\section{MATERIALS AND METHODS}

\section{Animals and Treatments}

The experiment was carried at Agrindus Farm, Descalvado, State of São Paulo, Brazil, Laboratory analyses were carried one at Animal Anatomy and Physiology Laboratory of the Animal Science Department, ESALQ/USP (College of Agriculture "Luiz de Queiróz", University of São Paulo) and also at the Laboratory of Electron Microscopy, coordinated by Dr. Elliot W. Kitajima (NAP/MEPA, Department of Entomology, Piracicaba, Brazil).

Twenty four males, newborn Holstein calves were randomly assigned to a $3 \times 2+4$ factorial arrangement, within the treatments: 1- low colostrum (calves fed colostrum with concentration less than $30 \mathrm{mg}$ $\mathrm{mL}^{-1}$ of $\mathrm{IgG}$ ); 2- high colostrum (calves fed colostrum with concentration more than $100 \mathrm{mg} \mathrm{mL}^{-1}$ of $\mathrm{IgG}$ ); 3- colostrum plus lyophilized colostrum (calves fed colostrum with concentration more than $120 \mathrm{mg} \mathrm{mL}^{-1}$ of $\mathrm{IgG}$ ) and two slaughter dates ( 24 and 72 hours of life). Two animals were slaughtered right after birth and two animals at 10 hours after birth as reference.

\section{Morphology procedure}

Calves were anesthetized and killed with barbiturate $^{1}$ according to recommended by Brazilian College of Animal Experimentation (COBEA). Tissue samples were taken from the duodenum, proximal, middle and distal jejunum and ileum. The small intestine segments were opened, the mucosa was flushed with saline solution, and the samples were fixed in cacodylatebuffered Karnovisky's fixative for 12 hours, and postfixed with $1 \% \mathrm{OsO}_{4}$ for 2 hours. After fixation, intestine sections (diameter@1.5 cm) were washed with cacodylate buffered $0.1 \mathrm{M}$ and dehydrated with acetone
$(30,50,70,90$ and 100\%, 10 minutes each concentration; 30 minutes at $100 \%$ ).

A critical-point drying apparatus (Balzers CPD$030^{2}$ ) was used to dry all tissue sections. Procedures followed recommendations of Anderson [1].

Processed tissues were fixed with adhesive to aluminum stubs and the sections were coated with 40 $\mathrm{nm}$ of gold in Balzers MED- $010^{2}$ sputter coater. The samples were examined with a scanning electronic microscope Zeiss DSM-940A ${ }^{3}$, at $5 \mathrm{kv}$, at magnifications from 70 to $900 \mathrm{X}$.

\section{RESULTS}

At birth, the duodenum villi a compacted and agglomerated forming anastomoses (Figure A), with homogeneous height. Villi were wide and short. Duodenum villi, at birth, were atrophied when compared those at 24 hours of life. Also at birth, the circular stratus muscularis tunic was not mature, and at 10 hours of life this structure was thicker and Brunner's glands were visible and well defined (Figure B). At 24 hours of life, Brunner's glands were not apparent, independently of the treatment (Figure F). In older animals, the duodenum's anastomose was reduced and the villi were less agglomerated and better defined.

In proximal jejunum at birth, the villi were finger-shaped (Figure D), homogeneous in height and uniform in direction. This segment was thinner than duodenum and the crypts of Lieberkühn were well defined. At 10 hours of life, the villi heights remained uniform, but irregularly shaped (Figure E). At 72 hours after birth, proximal jejunum villi showed tongue and leaf-like shapes. Independently of treatment and age, the villi of this segment looked shriveled (Figure G).

At all ages, middle jejunum villi were disorganized and presenting an homogeneous, tongueshape (Figure I), dissimilar to the proximal jejunum. The submucosa appeared thicker and Brunner's gland were more developed in animals that fed colostrum with low $\operatorname{IgG}$ concentration, in comparison to animals fed high IgG concentration.

In this study, at birth, the distal jejunum villi were tongue-shaped, thinner (Figure $\mathrm{H}$ ) and showed a roughened surface, especially in calves fed colostrum with high IgG concentration, with or without lyophilized colostrum. Animals fed colostrum with higher IgG concentration, showed the distal jejunum villi more compacted and without uniform direction, at 24 hours after birth. 

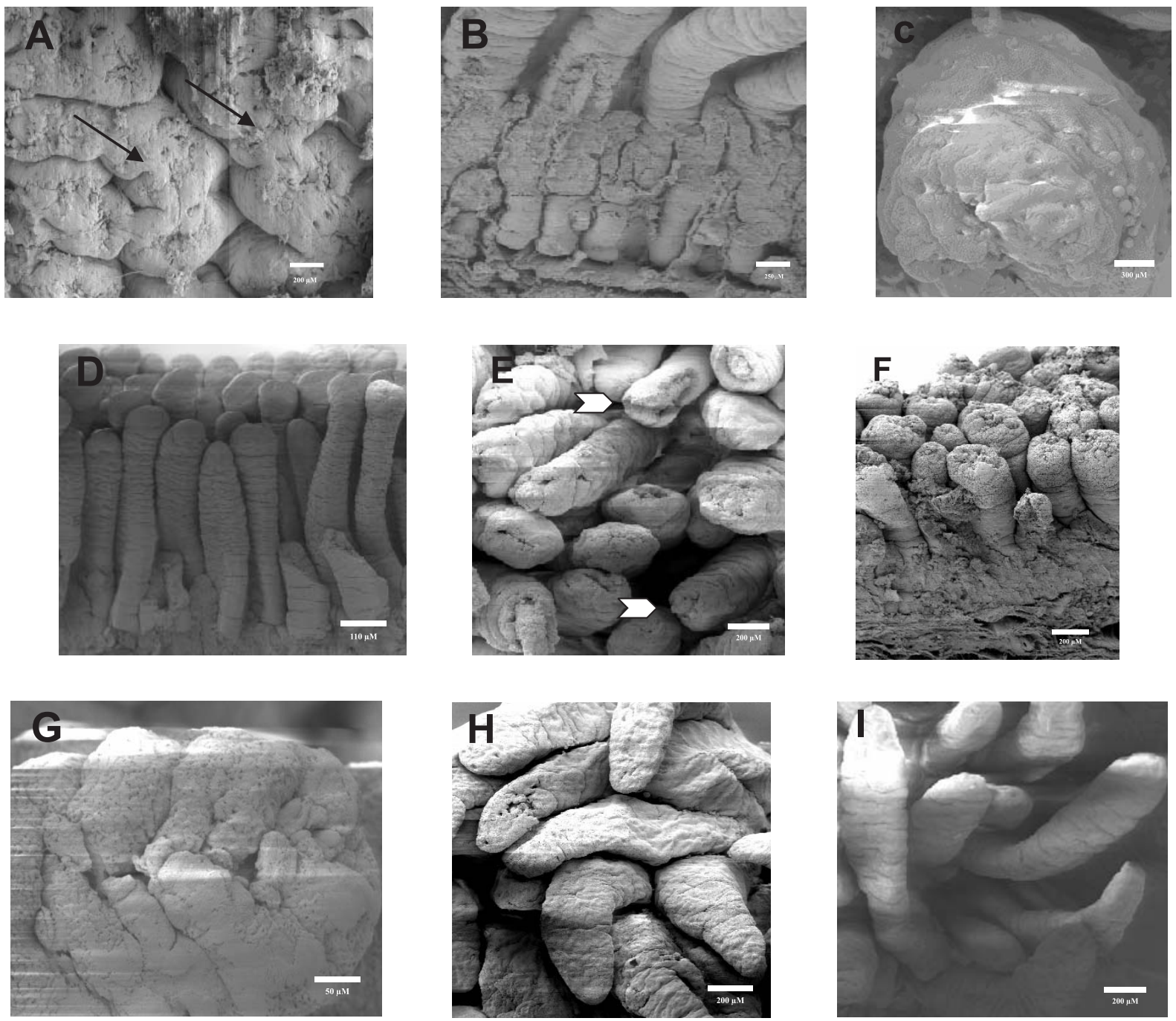

Figures: A. Duodenum's anastomoses at birth (X 130); B. Duodenum at 10 hours of life with Brunner's gland (X 200); C.Villus tip of the distal jejunum at the 24 hours of life, group 3, the arrow is circular stratus (X 310); D. Proximal jejunum at birth (X 74); E. Proximal jejunum at 10 hours of life (X 115); F. Calves duodenum at 24 hours of life (X 100); G. Proximal jejunum at the 24 hours of life (X 900); H. Distal jejunum at 24 hours of life, group 2 (X 105); I. Middle jejunum at 72 hours of life (X 100).

At birth, the ileum villi showed fingers-shaped and thinner compared to the other regions of the small intestine. However, with age, these villi were wider and tongue-shaped. Animals fed colostrum with high $\mathrm{IgG}$ concentration presented compacted, agglomerated, and less organized ileum villi, moreover this segment in the calves fed colostrums additional of lyophilized colostrums showed more Brunner's gland number in comparison another groups.

\section{DISCUSSION}

The homogeneous duodenum villi observed in this study (Figure A) was also seen by Bessi et al. [2]. Too, similarly, Bessi et al. [2] observed that duodenum's villi showed uniform size at 72 hours after birth.
Scanning electron microscopy revealed shorter villi in the duodenum in comparison to the other segments, independent of the treatment. However, the villi height varied between segments, and did not present uniform pattern. Besides, the villi of all segments presented wrinkled surfaces, numerous transverse furrows and extrusion zones at the tips of the villi (Figure G). Same observations were made by Mebus et al. [6].

Wiese et al. [8], working with pigs, found similar results in relation to the proximal jejunum villi shapes (Figure G). This measure possibility increases the contact surface with the quimo. Bessi et al. [3], using scanning electron microscope, recorded tongue-shaped and uniform distal jejunum and ileum villi in calves from 
birth to up 3 days of age, what also was seen in present study in the birth (Figure I). And, the circular stratus muscularis more development observed in distal jejunum villi in calves fed colostrums with high $\operatorname{IgG}$ concentration suggests that presence of the quimo require more peristaltic movements.

The addition of lyophilized colostrum to colostrum increased the number and the development Brunner's gland in the ileum in comparison to animals ingesting fresh colostrum with high $\mathrm{IgG}$ concentration, independently of the age.
CONCLUSION

The results of this study suggest that the use of colostrum with high IgG concentration, with or without lyophilized colostrum, influenced the precocity of the intestinal mucosa development in newborn calves inducing an earlier maturation of the mucosa.

\section{SOURCES AND MANUFACTURES}

${ }^{1}$ Vetanarcol ${ }^{\circledR}$, König do Brasil Ltda., Brazil

${ }^{2}$ Balzers, Oerlikon, Germany

${ }^{3}$ Carl Zeiss, Oberkochen, Germany

\section{REFERENCES}

1 Anderson T.F. 1951. Techniques for the preservation three-dimensional structures in preparing specimens for the electron microscope. Transactions of the New York Academy of Science. 13: 130-134.

2 Bessi R., Pauletti P., d'Arce R.D. \& Machado Neto R. 2002. Absorção de anticorpos do colostro em bezerros. I. Estudo no intestino delgado proximal. Revista Brasileira de Zootecnia. 31: 2314-2324.

3 Bessi R., Pauletti P., d'Arce R.D. \& Machado Neto R. 2002. Absorção de anticorpos do colostro em bezerros. I. Estudo no intestino delgado distal. Revista Brasileira de Zootecnia. 31: 2325-2331.

4 Blum J.W. \& Hammon H. 2000. Colostrum effects on the gastrointestinal tract, and on nutricional, endocrine and metabolic parameters in neonatal calves. Livestock Production Science. 66: 151-159.

5 Bülher C., Hammon H., Rossi G.L. \& Blum J.W. 1998. Small intestinal morphology in eight-day-old calves fed colostrum for different durations or only milk replacer and treated with long- $\mathrm{R}_{3}$-insulin-like growth factor-I and growth hormone. Journal of Animal Science. 76: 758-765.

6 Mebus C.A., Newman L.E. \& Stair E.L. 1975. Scanning electron, light, and transmission electron microscopy of intestine of gnotobiotic calf. American Journal Veterinary Research. 36: 985-993.

7 Rauprich A.B.E., Hammon H.M. \& Blum J.W. 2000. Effects of feeding colostrums and a formula with nutrient contents as colostrum on metabolic and endocrine traits in neonatal calves. Biology of the Neonate. 78: 53-64.

8 Wiese F., Simon O. \& Weyrauch K.D. 2003. Morphology of the small intestine of weaned piglets and a novel method for morphometric evaluation. Anatomia Histologia Embryologia Journal of Veterinary Medicine Series. 32: 102-109. 